Revista Iberoamericana. Vol. LXVI, Núm. 192, Julio-Septiembre 2000, 661-676

\title{
LECTURAS CON SABOR A CHOCOLATE DE CEREZAS: CONVERSANDO CON MARGO GLANTZ EN COYOACÁN ${ }^{1}$
}

\author{
POR \\ IRMA Velez \\ The City College-CUNY
}

\begin{abstract}
Apenas cuelgo el teléfono y me deja absorta esa voz temerosa que me advierte llegar a su casa de Coyoacán con un taxi de sitio, o en metro, porque en México, "están pasando cosas feas". Pero en la calle de Meca, quien no entra no peca, y a las pocas horas de esa breve conversación con Margo Glantz, me recibe exultada Lola, la perra de Margo, rogándome caricias con una mirada dócil. Llego demasiado temprano y esperando a Margo descubro su espacio casero desde el living, adonde me hurta la mirada un retrato de su padre, iluminado por la luz que entra del jardín. Margo rompe el silencio bajando por unas escaleras con un atuendo verde suntuoso. En ese preciso momento me cohibe el haber provocado semejante invasión en la vida de una escritora a quien veo en ese momento por tercera vez, en un espacio de unos días, entre Santiago de Chile y el Distrito Federal. Nos saludamos cordialmente y le confieso que la veo más relajada que la víspera, en la clausura de las V Jornadas Metropolitanas, en las que participó en un homenaje a Jean Franco. Concurrió a una mesa, a la que llegó apurada por el congestionante tráfico de la capital, y se le habían quedado en el rostro huellas de postración urbana. Nos observamos ahora con serenidad, reconciliando el desconocimiento mutuo de esta inusitada presencia de la una ante la otra. Prendo la grabadora, mientras me sirve un café. Se sienta y despeja la mirada con destellos de curiosidad y deleite. No sabe que sólo resisto el té de hierbas pero me abandono a la placentera idea de un encuentro cafeinado tras haber comprobado, con gran alivio, que México tiene un metro muy civil.

IRMA VELEZ: ¿Escribir Las genealogías fue un proyecto que venías preparando desde mucho tiempo?

Margo Glantz: No, fue una cosa que se me ocurrió de repente. Fue una circunstancia un poco trágica que recordó otra circunstancia trágica y que me hizo escribir una columna en el periódico Unomásuno. Desde ese momento decidí recobrar las memorias de mis

\footnotetext{
${ }^{1}$ Esta entrevista, corregida y editada por Margo Glantz de acuerdo con la entrevistadora, se llevó a cabo el 11 de julio de 1998, en Coyoacán, México D.F., a raíz de la participación de Margo Glantz en dos congresos internacionales: el XXXII Congreso Internacional de Literatura Iberoamericana, "Fines de Siglo en la Literatura Latinoamericana: Crisis, Apocalipsis y Utopías", Pontificia Universidad Católica de Chile, Santiago de Chile, 29 junio-3 de julio de 1998; y en las V Jornadas Metropolitanas de Estudios Culturales, “Arte, Literatura y Crítica en México y en América Latina”, Centro de Cultura Casa Lamm, México D.F., México, 8-10 julio, 1998.
} 
padres a través de una grabación. No que necesariamente el texto haya empezado a publicarse por entregas de la manera como se publicó ya el libro. Pero sí de repente esas circunstancias biográficas, que recordé por otra circunstancia biográfica trágica, me dieron la pauta para escribir la vida de mis padres. Y eso lo hice a partir de una especie de trabajo folletinesco, totalmente fragmentario: la fragmentación de la conversación grabada y la fragmentación de la publicación semanal, por entregas. También la grabación es una grabación entrecortada con un discurso un poco retorcido, y más que retorcido sinuoso, cortado porque no llega a algo muy definido lógicamente, sino a recuerdos que son así como sueltos, como uno recuerda mentalmente, como trazas de la memoria, que se dan grabando directamente de la grabadora y que luego hay que reconstruir.

IV: Sin embargo, a partir del capítulo diecisiete desaparece la grabadora y se va imponiendo tu propia voz. Dejas a un lado las lecturas de tu familia y vas incorporando tus propias lecturas, sobre todo las que pertenecen a la producción literaria propiamente nacional. ¿Qué papel tuvieron las primeras lecturas, las que salen de la biblioteca de tus padres?

MG: En realidad hay una cosa artificial en el recuerdo de las lecturas de mis padres porque yo no estuve demasiado cercana a esas lecturas aunque estuve muy cercana a los libros. Yo estuve rodeada de libros como una especie de paisaje de mi infancia. Eso es algo fundamental. Las casas de mis padres son casas con libros. Mi padre era un hombre con libros, era un poeta que siempre se desplazaba con sus libros. Una de las cosas que hizo fue desplazarse con libros desde Ucrania con, como dicen en Chile, plumones: esas colchonetas llenas de plumas.

IV: ¿Y pudieron desplazarse con los libros sin dificultad?

MG: Sí. Mis padres huyeron de la Rusia que empezaba a ser estalinista. Y aprovecharon esa coyuntura que era la posibilidad de... Suena el teléfono dejando en suspenso la conversación. Margo le ruega a Mari que apunte las llamadas y que no la interrumpa. Le surge una nueva idea y prosigue... Una coyuntura importante era que mi padre tenía una parte de su familia en los Estados Unidos y que esa parte de su familia ayudó a los que quedaron en Rusia a emigrar. Y vino mi abuela, mis dos tías y mi padre, que era el menor de la familia. Mi padre se casó con mi madre y emigraron con algo de ropa, con objetos de la casa, con recuerdos, ¿¿no? Mi madre dice que tenían un gran baúl lleno de libros. Yo me pregunto si eso es cierto.

IV: ¿Por qué no habría de serlo?

MG: Bueno... hacr una pausa, esquivando la nueva pregunta y en un ademán que confirma su fidelidad a la duda prosigue... Y además, yo heredé, más bien una hermana mía heredó, el cofre. Esos cofres inmensos que se llevaban en los barcos en donde venía la ropa de mis padres, ¿no? Entonces, había ese recuerdo del frío. Los colchones, los cojines, esas colchonetas de pluma, que yo recuerdo de mi infancia, cuando nos tirábamos en la cama con mi papá y con mi mamá. Era una cosa así como muy suave y muy ligera. Sus ojos cobran en este instante un viso risueño y melancólico a la vez. Era sinuosa, tierna, acariciante, caliente, cálida. Era muy bonita. Eso va muy unido a los libros y, además —y eso lo digo en las Genealogías - como nunca mis padres tuvieron muchas posibilidades de manejar su economía, íbamos descendiendo y cambiábamos de habitación muy a menudo. Y en esos cambios, siempre había mudanzas, camiones de mudanzas con grandes cajas llenas de 
libros. En aquella época, las cajas eran de madera y muy grandes. Y había los cargadores que cargaban con una reata, una cosa casi prehispánica, y montaban los libros —a veces vivíamos en el cuarto piso sin ascensor. Y subían sus libros los cargadores con las venas casi reventadas. Y a mí, me afectaba mucho ese tipo de cosa. Entonces el libro para mí es como un...

IV: ... fue el peso de la cultura...

MG: Sí, demasiado. Sé que mi madre leía a Dostoievski, sé que mi madre leía a Tolstoi. Mi madre era una mujer culta. Y alguna vez me habló de eso, pero no tanto ella como amigas de mi madre que me recomendaban que yo leyera en ruso, que me decían ¿por qué no lees un texto en español con una versión en ruso y aprendes?, porque leer a Dostoievski en ruso es maravilloso. Yo me acuerdo de una señora que vivía donde nosotros vivíamos cuando yo tenía once o doce años y que decía eso. Y sin embargo mis padres no tuvieron mucho tiempo de recordarme qué tenía que leer. Como que no se ocupaban mucho de eso mis padres. Estaban muy ensimismados en su vida de pareja y en su vida económica, que era siempre complicada, yo me imagino. Mi madre estaba siempre con la culpabilidad, eso me lo imagino yo, de haber abandonado a toda su familia en la Unión Soviética y que no volvió a ver nunca, ni a sus padres, ni a sus hermanos. Todo eso me imagino que debe haber pesado sobre mi madre que la tenía bastante ensimismada. Y además la vida cotidiana era muy difícil para ella. Era una mujer muy mimada en su casa, la única hija entre varios varones. La consentían mucho. Entonces, de repente llega a México y se da cuenta que tiene que enfrentarse a la vida cotidiana que es bastante dura, con un padre y con un marido que era completamente impráctico, ¿no? Entonces ella tuvo que desplegar su practicidad.

IV: ¿Y cómo manejaron la cuestión del idioma? ¿Cuántos idiomas se hablaban en tu casa?

MG: Mira, en la casa se hablaba en ruso y en yiddish, pero en realidad el idioma que yo hablaba era el español porque mis padres no hablaban conmigo ni en yiddish, ni en ruso. Yo no sé nada de ruso. Sé da, niet, pricasnaia, spasiva ese tipo de palabras, ¿no? Pero nada más. Chorni. Esas palabras que oía yo de mis padres y mi padre, a veces, cantaba canciones en fiestas cuando llegaban los otros amigos rusos, los judíos rusos que venían de Nueva York por ejemplo.

IV: En las Genealogías, cuando incorporas voces extranjeras, sueles traducirlas, o sea que escribes para un lector mexicano, ¿no es cierto?

MG: Ha, ha, dice en tono aprobatorio. Pero yo descubro con claridad ciertas cosas sólo a través de la escritura; es cuando escribo que las cosas adquieren forma y afloran a la conciencia.

IV: ¿Opinas, como Rosa Nisán, que eres una escritora mexicana más que una escritora judeo-mexicana? ¿O estableces al contrario y a partir de las Genealogías una filiación cultural con el judaísmo?

MG: En las Genealogías, no en otros textos, yo diría que soy escritora judeomexicana. Totalmente. Es un texto en donde yo estoy totalmente relacionada con mis orígenes. ¿No quieres unas galletitas o algo? Me pregunta con una voz cariñosa. Demasiado absorta en su narración me niego con un leve cerrar de ojos y le devuelvo una mirada inquisitiva que rescata sus palabras ...Me considero una escritora judeo-mexicana en este texto, no en todos los textos que yo escribo. 
IV: ¿O sea que no escribes siempre como judeo-mexicana?

MG: Es una pregunta difícil. Yo creo que sí, que escribo como judeo-mexicana porque soy judeo-mexicana, pero conscientemente como una escritura en donde el judaísmo sea una cosa totalmente concreta y directa, no. Pero creo que siempre pasa por mí, como pasa por mí ser mujer y ser judía. Lo judío para mí es muy importante, es importantísimo y no puedo prescindir de eso, aunque yo me siento muy mexicana también. Pero, lo cierto es que los dos componentes son absolutamente importantes.

IV: ¿Qué propósito tenías al escribir una narrativa testimonial y documental como las Genealogías en la que te sirves tanto de la grabadora como de documentos fotográficos y oficiales?

MG: La estructura fue coyuntural. Me imagino que lo coyuntural siempre tiene una explicación inconsciente mucho más profunda que la casualidad. De chica, mis lecturas favoritas son las del folletín. Entonces la estructura de ese libro es la del folletín. Si tú planteas esa estructura bibliográfica, es absolutamente la del folletín. El folletín procede por entregas. Son fragmentos que se van entregando al periódico, cosa que yo exactamente hice y muchas veces.

Yo creo que el folletín va acompañado de grabados en donde se visualiza y se concretiza la figura de un personaje que antes ha sido escrito con la palabra, no con una descripción muy larga como se usaba en el siglo XIX, de una manera congelada para describir al personaje. Esa acción congelada que vuelve a reproducir en la figura de un personaje que se va a volver tan memorable como la descripción escrita.

IV: ¿O sea que es a partir de una relación afectiva con el folletín que elaboras la estructura de esta obra?

MG: Yo creo que sí, es una relación que tiene mucho que ver con un chocolate de cerezas, confiesa con las párpados trepidantes de placer, y tangos que yo oía de niña al mismo tiempo que leía Los tres mosqueteros. Yo me sentaba en un cuarto que teníamos y que estaba alejado del resto de la casa, que estaba bastante caótica porque vivíamos cuatro hermanas y estábamos todas en un cuarto. Entonces, me subía en esa sala que era como un recinto medio sagrado, casi sangrado, como un vientre, separado del resto de la casa, donde yo estaba leyendo y al mismo tiempo comiendo chocolates que eran especiales. Tenían una especie de membrana exterior que era papel de estaño con florecitas al que yo alisaba con las uñas, y que guardaba en libros justamente. Pierde la mirada por un instante en el recuerdo resucitado de las manos que ahora contempla. Y aparte de eso, me comía el chocolate que estaba relleno con una cereza, rodeada como en un vientre justamente, de licor, que sería la placenta con el agua materna. Todo eso. Allí, estaba yo sentada oyendo tangos, esos tangos trágicos, terribles en los que los hombres abandonaban a las mujeres o las mujeres a los hombres más generalmente, sonríe. Y leyendo folletín. Mi texto tiene que ver con el folletín. El folletín es una cosa que yo he trabajado mucho y ahorita estoy escribiendo un libro justamente sobre el folletín mexicano. Vuelve a sorber un traguito de café. El estampido de la taza sobre el plato interrumpe la oración... que me parece en el origen de la literatura mexicana muy importante, en Los bandidos de Río Frío de Manuel Payno, que no leí de niña porque leí el folletín francés pero no leí el folletín mexicano. Leí el folletín mexicano como profesora de literatura, pero ya mucho más tarde, y, sin embargo, mi relación con las genealogías, y no me había dado cuenta nunca hasta ahora que me lo 
preguntas, es una relación con un pasado de lecturas que para mí es la cosa más importante como paisaje biográfico, los libros, y una cercanía con la escritura leída, con la escritura impresa, porque tenía yo dificultad de relación social. De chica, me mudé muchísimo de escuela. No tuve tiempo de hacer amigas en las escuelas porque a veces estaba dos meses, tres meses, seis meses y entonces me mudaban de escuela por mis papás que cambiaban de casa. Y era yo muy tímida además también. Entonces mi relación con el mundo pasaba por la hoja impresa.

IV: ¿Piensas como Albert Memmi, que "un homme assit entre deux cultures est toujours un homme mal assit”? ¿Crees que una mujer sentada entre dos o varias culturas es también una mujer mal sentada y que su voz puede verse doblemente amenazada por su condición transhistórica y transgeográfica?

MG: Creo que es tan habitual ahora la situación intercultural. Tú que vives en Estados Unidos lo sabes perfectamente. Acabo de venir de Berkeley y verdaderamente es impresionante la multiculturalidad que hay.

IV: Pero de Estados Unidos, a veces se desprende una visión idealizada del meltingpot que no necesariamente corresponde a la realidad. Habría que distinguir entre una situación intercultural que sería propia del melting-pot, y un convivir multicultural por la cercanía de los distintos grupos étnicos, con sus variantes sectoriales, que me parece definir mejor la vivencia estadounidense de hoy día.

MG: Yo creo que hay un melting pot, y que ese melting pot se nota en la gente que ya existe en Estados Unidos. Las nuevas oleadas de emigrantes van formando como núcleos aislados en Estados Unidos y, además, como en todas las culturas hegemónicas se trata siempre que lo otro se separe y que haya una delimitación muy clara de los otros para que los "verdaderos" no se mezclen con los "otros" y se mantenga su cultura. Cosa que en México se hizo al revés. Se apresura a matizar. Los indios fueron mantenidos aparte, fuera de la ciudad española, físicamente; cosa que aún puede verse hoy en San Cristóbal de Las Casas, en Chiapas. Los indios fueron los pobladores originarios de este país y fueron marginados, aunque esa marginación nunca fue total, era imposible, porque los indios participaban en las labores esenciales de servicio, constituían el paisaje urbano y rural. Los españoles trataron de mantenerlos aparte y nunca lo consiguieron totalmente, lo mismo que en los Estados Unidos, pero creo que de manera radicalmente diferente. Tienes razón, Estados Unidos parece multicultural, y la gente parece homogeneizarse, pero hay una separación entre etnias y culturas, en San Francisco, por ejemplo los barrios son muy definidos. Son barrios culturales: el barrio chino, el barrio japonés. Y la gente sube en el autobús y empiezan a subir chinos y pasas el barrio y suben irlandeses. Es cierto. Ahora cuando yo nací en México, México no era un país de emigrantes. Evidentemente, la inmigración se notaba. Yo lo sentía de una manera total.

IV: ¿Entonces lo sufrías?

MG: Lo sufría de una manera anecdótica. No sé si eso me dejó heridas muy profundas. Yo por ejemplo, muy banalmente sufría porque el 6 de enero, que cuando yo era niña era el día de los Reyes, era el día cuando se regalaban cosas en México. No se regalaban el 24 de diciembre. Luego se volvió una costumbre importada por el consumismo pero cuando yo era niña, era el día de Reyes. Yo vivía siempre en barrios no judíos, porque mis padres no tenían dinero para vivir en los barrios donde vivían los judíos. Entonces en esos barrios, 
todos los niños salían con muñecas. Las niñas, que es en lo que yo me fijaba, las niñas. Salían con tacitas de té, con casitas. Entonces yo decía cada vez: “¡Caray! ¿Cómo no soy goi? ¡Yo quisiera ser goi!” Todos los 6 de enero, me asomaba debajo de la cama, a ver si había juguetes. No había. Le dilatan las pupilas un saudade infantil. Entonces fue una situación totalmente coyuntural, anecdótica. Probablemente me dejó huellas indelebles que no recuerdo muy bien, que no he podido reconstituir. Yo soy muy judía pero al mismo tiempo estoy totalmente fuera del judaísmo.

IV: ¿Entonces, si no has sufrido de tu vivencia pluricultural, cómo te has relacionado con la comunidad judía?

MG: No soy grupalmente judía. Soy culturalmente judía, no dentro de un judaísmo muy tradicional de emigrantes sino dentro de un judaísmo de gran escritura, Kafka, Benjamin, Celan, Bruni Ganz, Joseph Roth, Primo Levi, Hanna Arendt.

IV: Tu obra me ha interesado mucho por ser un texto autobiográfico en el que la lectura se convierte en un aspecto primordial de la representación del sujeto. Como en muchos otros discursos autobiográficos protagonizados por un lector, rescatas esa relación tan seductora entre la lectura y la vida ¿Por qué crees tú que ese coqueteo entre la imaginación y la memoria seduce tanto? La reiterada relación entre biografía y bibliografía llama la atención por ejemplo a la hora de constatar la deserotización del texto que sigue una tradición autobiográfica sexualmente "inmaculada".

MG: Yo pienso que hay una deserotización consciente en el texto porque habla de los padres. Y al hablar de los padres, lo erótico se vuelve muy tabú, porque uno está vinculado a la erotización de los padres y la tiene que negar de alguna forma. Yo creo también que es como un movimiento que te produce la escritura: no escribes de los padres hasta que eres bastante viejo. No necesariamente, se refuta, no hay reglas, digamos. Pero yo escribí ya bastante vieja porque eran padres viejos también, padres que estaban perdiendo la memoria, padres que yo quería recuperar y que al mismo tiempo nunca había tratado de recuperar porque eran demasiado cercanos. Estoy leyendo un libro maravilloso sobre el cuerpo virginal de una historiadora italiana que vive en Francia, ... baja el tono para marcar la pauta de una digresión y mengua la voz que sale ahora de la grabadora... y está trabajando sobre el problema del cuerpo virginal en la literatura de los griegos. Es Giulia Sissa, discípula de Nicole Loraux. Y el libro es Le corps virginal. Hizo la tesis con Nicole Loraux y la publicó en el 87, en la Librairie Philosophique J. Vrin ... vuelve a alzar el tono, regresando a la pregunta con ímpetu. Ella habla de todas las prácticas del oráculo de Delfos, que siempre son transmitidos por la Pitia, que es una virgen. Era tan absolutamente conocido el oráculo, que la gente que escribe sobre el oráculo no se pone a describirlo, porque es una obra tan común que nadie tiene que recurrir a una explicación, una descripción, para estar familiarizado con él. Añado lo siguiente, aunque parezca truculento y no viene el caso: el oráculo de Delfos se realiza como decía, a través de la profetisa, la Pitia, quien está sentada sobre un montículo que deja escapar emanaciones geológicas, y la transmisión de la profecía sigue un transcurso demasiado corpóreo, casi pornográfico, porque pone en juego las dos bocas del cuerpo femenino, la vagina por donde penetran los efluvios oraculares a través de la vagina que desde el fondo de la tierra envía el dios Apolo, y esas emanaciones pasan por el útero y desde allí a la boca de la profetisa para transformarse en palabras organizadas que transmiten el oráculo al sacerdote que ha hecho la consulta. Esta relación de lo oracular con el cuerpo es tan violenta que casi nunca se verbaliza en Grecia. 
De manera indirecta me parece que eso sucede en un libro que trata de quienes lo han engendrado a uno, desde sus bajos vientres.

IV: Aunque al final de las Genealogías ese bajo vientre regresa cuando te describes orinando en una playa.

MG: Claro, pero soy yo la que orino, y mi hija está al lado. Quizá sería el único dato muy corporal que hay en el texto. Y decía yo "Por fin hay algo caliente que me toca los muslos", porque estaba yo sin hombre desde algún tiempo, porque estaba separada de mi marido. Y hay también una cosa importante y que es la relación con mi marido, que es una relación cursi. Lo encuentro en la Argentina, porque mi marido era argentino, mi segundo marido, el papá de mi segunda hija. Y fuimos juntos a la Argentina en nuestra luna de miel. Entonces, hay un recuerdo de la Argentina, y allí hay un recuerdo sentimental y sexual, pero muy desvanecido como recuerdo sexual. Es la única sensación totalmente corporal y adonde hay una nota de sensualidad directa, o indirecta porque es la orina.

IV: En muchas autobiografías y memorias de mujeres, se manifiesta la necesidad de encontrar lo que Rosario Castellanos llama “lecturas para mujeres". No me ha parecido sin embargo ser una de tus preocupaciones principales en las Genealogías. ¿Existió en algún momento esa necesidad para ti?

MG: Sí, la había porque en el folletín estaba Corín Tellado, que también menciono en el texto. No, no Corín Tellado que no estaba en la época, vuelve a corregirse. Leía yo a M. Delli, quien luego supe, era una especie de consorcio o industria escrituraria que producía novelas sólo para mujeres, como Corín Tellado, novelas rosas, y además leía novelas pornográficas que había en la biblioteca de mi padre, que era una biblioteca un poco desordenada.

IV: ¿Te dejaban leerlas?

MG: Mis padres no tenían tiempo para ocuparse de nosotras, mis padres no tenían demasiado tiempo para mirarnos y aunque en Genealogías están muy presentes, lo estaban de otra forma, como vivencia cálida, como atmósfera familiar estructurada a pesar de todo, pero estábamos bastante solas, bastante descuidadas, ellos estaban absortos en su pelea con la vida, en su relación cotidiana con los problemas exteriores: mi padre en su Narciso y en su poesía, y en la difícil tarea de ganar dinero y mi mamá era obsesiva con mi padre, se hacía a través de él, como las mujeres de ese tiempo, la mujer se realizaba en pareja, y la obra de mi padre era también obra suya. Aparte la vida cotidiana, la tarea de vender zapatos o hacer pasteles en el restaurán Carmel, mi mamá tenía poco tiempo para nosotras. Entonces no se fijaban si yo leía. Mi papá tenía muchos problemas porque mi papá tenía mucha curiosidad por lo erótico y tenía novelas pornográficas, el Caballero audaz y todo eso. Yo leí esas novelas, y no entendía mucho porque tenía nueve o diez años. Pero leía las de M. Delli que eran maravillosas, y siempre me imaginaba a un novio. Yo llegaba vestida de blanco, como debe de ser, a una iglesia, precisamente, con un novio vestido de smoking, que no tenía cabeza, pero la cabeza estaba coronada, aunque no se la veía yo por un sombrero de copa. Entonces ésa era para mí una imagen que venía de la novela rosa.

IV: ¿No sentiste por lo tanto la necesidad de buscar lecturas para mujeres en el sentido que le da Rosario Castellanos, para colmar "la osadía de indagar sobre sí misma”? ${ }^{2}$

${ }^{2}$ En “La mujer y su imagen”. Mujer que sabe Latín, México: Fondo de Cultura Económica, 1992. 7-21 
MG: No, saciaba mi curiosidad romantizada, mi romanticismo de adolescente, en la novela de M. Delli. También el folletín se prestaba al romanticismo porque siempre hay las heroínas que sufren y que son impuras como Flor de María en los Misterios de París de Eugenio Sue que yo leía. Ahí saciaba yo esa nostalgia muy romántica. Y los tangos eran muy importantes. Y habría cosas así, Rosita Quiroga, delgadita, delgadita, que hablaba de un hombre al que adoraba: "Negro, quiero darte a ti toda la vida”, entonces esas inflexiones de Neeeeegroooooo que me fascinaban y me penetraban el corazón como el chocolate de cereza que pasaba por mi garganta con su sabor empalagoso y ligeramente alcohólico.

IV: ¿Cuáles fueron algunas de las lecturas más impactantes que recuerdas?

MG: Yo leía muchísimo. Desde los catorce años o quince, empecé a leer a Faulkner. Por ejemplo me impresionó muchísisisimo Santuario que no entendí muy bien porque es una novela muy complicada. Leí Mientras agonizo, leí muchísimo a Sinclair Lewis, leí a Dos Passos. Especial de la cruz no lo entendí, lo dejé. Leía muchísimo la novela alemana. Por ejemplo Los sonámbulos de Broch, que es una novela muy difícil pero yo la leía desde chica. No sé qué me quedaba. Leía yo muchísimo, mucho de los autores que tuvieron que dejar Alemania por el nazismo como Lyon Feuchtwanger, Jakob Wassermann, Stefan Zweig, quien murió en Brasil y escribió Amok, también leí mucho a Herman Hesse, Romain Rolland, Roger Martin du Gard, y mucha novela norteamericana, Sinclair Lewis, Faulkner, Caldwell, muchísimos autores que estaban de moda entonces como Theodore Dreiser, Wolf. Y leía muchísima novela europea. Todo el folletín: Dumas, Hugo, Sue y en especial Balzac. Empecé a leer a Proust pero lo dejé porque no lo entendí en ese momento. Leía yo mucha tragedia griega. Leía a Shakespeare y releía mis primeras lecturas. Y trabajaba muchísimo dos tomos de poesía de mi papá, y que ahora tengo yo, desde la época griega hasta los años treinta. Leía a Safo, a los líricos griegos. Leía a los romanos. Muy sin entender, muy indigesto junto con novelas pornográficas, y era yo una lectora voraz y sigo siendo una lectora voraz.

IV: ¿Como lectora también te han interesando los géneros del yo?

MG: Me han interesado siempre las autobiografías, me han interesado muchísimo los diarios.

IV: ¿Recuerdas algunos en particular?

MG: Mira, los he leído más en los último veinte o treinta años. Los diarios de Mircea Eliade me parecieron muy impactantes y me pareció terrible descubrir luego que en su juventud Eliade había sido nazi. Porque, además, yo lo conocí a él en casa de una amiga que estudiaba la historia de las religiones, Laurette Sejourné. Siempre leí mucho los textos teóricos de Eliade y luego de repente me encontré con sus diarios. Hay dos tomos publicados en Francia y me impresionaron muchísimo. Desde muy niña leí los diarios de Kafka, desde los dieciséis años, eso sí me acuerdo muy bien. Leí mucho a Katherine Mansfield. A Virginia Woolf, pero últimamente. He leído las cosas de Mann por ejemplo. Luego muchas biografías también.

IV: ¿Cómo lees esos textos?

MG: Para mí la vida literaria es la vida diaria. Mi biografía es literaria. He hecho cosas también en la vida. Viajo, he tenido amantes, he usado el cuerpo, me visto. Pero una parte muy importante para mí es lo que leo. Mucho de lo que yo soy es lo que he leído. Entonces me parece muy importante saber cómo, en qué momento y en qué circunstancias ciertas 
cosas van a producir literatura. Me gusta mucho la vida de Conrad, me gusta mucho leer cartas de Conrad.

IV: ¿Experimentas la mirada culpable del voyeur al leer esos discursos?

MG: Claro, como un voyeur. Pero no me siento culpable, me siento fascinada. Es un voyeurismo feliz. Me siento culpable en otras cosas pero en eso no. Me encanta. También, cómo me aclara las cosas de mi vida personal, mi relación con mis hijas. Entro en terrores también. Me impresionó mucho las Memorias de un opiómano de Quincy. Pienso cómo su madre lo descuidó y algo terrible le pasó y empezó a fumar opio. Y cómo eso determinó totalmente su vida, lo acabó y al mismo tiempo produjo una literatura maravillosa. Y entonces me produce una violencia y espero que lo que yo hice no le vaya a producir a mis hijas algo terrible.

IV: En una entrevista con Mercedes Valdivieso dices “me ha preocupado enormemente trabajar en la literatura la visión del cuerpo, porque mientras no nos demos cuenta de cómo nos han visto, no nos podemos ver nosotras”. ¿Cómo responderías tú entonces a Jean Franco, a Mabel Moraña y a Nelly Richard entre otros críticos, que denuncian una división del trabajo en la que se pone a Latinoamérica en el lugar del cuerpo mientras que el Norte se convierte en el lugar de la cabeza que la piensa y que la somete a una teorización reduccionista? En definitiva, ¿cómo resuelves tu interés esencialista sin caer en las trampas tan amenazantes del mercado, de las que habló Diamela Eltit en el Congreso del IILI en Chile?

MG: Mira, quisiera caer en las trampas del mercado para comprarme un departamento en París porque esta ciudad ya no me gusta, afirma con socarronería. Entonces quisiera yo poder estrenar una obra maravillosa para ganar dinero, que me leyeran en Francia, en Estados Unidos y aquí en México, y que estuviera cuarenta y dos semanas en la lista de Best Sellers en el New York Times. Risas. Pero no voy a poder estar. Entonces lo que yo escribo es generalmente poco leído, porque escribo cosas así como oscuras con géneros no determinados, con el fragmento, con personajes que en realidad son obsesiones como en Signo de naufragios, una novela en donde se narran todo tipo de tempestades, desde el Diluvio hasta una tormenta en un vaso de agua, y entonces a la gente en general no le interesa. Ya no sé si te contesté, pero creo que no hay ningún esencialismo en lo que digo, es más bien, como ahora se dice tan continuamente, una deconstrucción del cuerpo femenino o un problema de antropología cultural o de historia de las mentalidades, a la manera en que mucho tiempo después de escribir por ejemplo, La lengua en la mano y Esguince de cintura o De la amorosa inclinación a enredarse en cabellos, corroboré en Nicole Loreaux o en Piero Camporessi. Se trata de una mirada sobre lo femenino, sobre aquello que en general la historia no ha trabajado porque por ejemplo en Grecia, como bien lo muestra Loreaux, se considera que la ciudad está constituida sólo por los hombres y ella explora entonces lo “otro", es decir lo femenino en la ciudad y por lo femenino inexorablemente pasa el cuerpo. Mira, no tengo temor de ciertos discursos críticos femeninos, admiro mucho a todas las críticas que mencionaste, la imagen del cuerpo oprimido como Latinoamérica y la cabeza rectora como el Norte es muy significativa y me recuerda un viejo emblema que alegoriza a la monarquía en Europa: la del Rey como cabeza y la del cuerpo como pueblo con sus divisiones muy específicas, pues a cada parte de la anatomía corresponde un estamento social. No es que no me interese lo teórico, pero en este tipo de diálogos privilegio lo narrativo. 
IV: Sin embargo, ¿no sería sensato pensar que tu propia labor creativa compite con tu labor crítica y se deja afectar sobremanera por ella?

MG: No, mi labor creativa tiene que ver con mi labor crítica, son vasos comunicantes, siempre que voy a escribir un texto, no las Genealogías, pero tú me dices que está muy vinculado con la bibliografía, después que yo pensé que era el libro más inocente que había en mi escritura, pero no y tú me lo revelas, lo cual me emociona. Pero todo lo que yo he escrito está vinculado con mi voracidad de erudición, que yo creo que la manejo muy bien, sin modestia. La manejo bien porque es una erudición golosa, gastronómica. Es una erudición que para mí es fascinante, como comprarme ropa, como comprarme zapatos, como comprarme cuadros.

IV: ¿Al escribir un texto literario creativo, no te autocensura, aun por deformación profesional, tu propia tendencia crítica?

MG: Probablemente me ha dañado inconscientemente porque he empezado a escribir tarde. Y mi primer libro de ficciones y cuentos, malísimos, en la década de los '60, no me interesa. Pero empecé a escribir mi primer libro de ficciones en el 77, que se publicó en el 78 y que fue un libro que salió directamente de mi cuerpo, es un texto confeccionado con mi gordura, escrito o mejor pensado en un país en donde la obesidad, la anorexia y la bulimia forman parte fundamental de la cultura. Yo estaba en Estados Unidos comiendo muchísimo, sobre todo Oreo Cookies, risas, y empecé a engordar enormemente. Y entonces de repente dije: “¡Qué barbaridad! ¿Qué puedo hacer? Hija, voy a escribir una novela dietética que se llamará Las mil y una calorías”. Y entonces empezamos a hacer epigramas, o más bien fábulas cortitas que decidí imprimir con letra enorme y gorda. Mi sobrino Ariel Guzik al que adoro, que es herbolario, músico e inventor maravilloso, un genio, me hizo los dibujos. Entonces hicimos el libro a mano y lo imprimimos casi a mano y nadie me lo quiso publicar. Yo lo publiqué a cuenta de autor y es un libro que surgió de la necesidad de relacionar mi cuerpo con la escritura y al mismo tiempo con la voracidad y la belleza de comer cosas ricas, dulces, pasteles que me encantan. Mis lecturas tienen que ver con eso; y de alguna forma cuando leo, lo relaciono con la escritura, pero probablemente no haya encontrado la organización textual y como yo soy tan voraz y leo tanto y tengo tantas referencias que no sabría cómo meterlas. Las puedo meter en un artículo, ¿¿no?, porque estoy escribiendo sobre crítica y me cuesta un trabajo horrible aunque lo hago rápido, pero escribir creación me es placenterísimo, extraordinariamente placentero.

IV: ¿No piensas entonces como Umberto Eco y Alberto Manguel que la lectura es otra forma de adulterio?

MG: En la escritura hay mucho de eso. Más bien que adúltero, me parece un placer sensual, casi orgásmico. Yo diría que mi cuerpo está totalmente vinculado a la escritura. Y por eso mi escritura es bastante erótica, Apariciones es una novela erótica, una novela quizás un poco atormentada y flagelante, pero es una novela gozosa en muchas cosas, a pesar de que trabajo cuerpos de mujeres atormentados por la autotortura, que son bastante violentos. Pero creo que hay una erotización muy grande en mi cabeza cuando escribo. Cuando escribo un ensayo, hay una erotización teórica pero que no pasa al placer de la escritura. Cuando escribo ficción, hay una erotización total, corporal. Yo siento el cuerpo, y siento un placer casi obsceno. En Apariciones, yo escribo cómo escribo. Describo algunas formas de escrituras que no son necesariamente las mías, pero que me parecen maravillosas, un poco como la Pitia. 
IV: Si tu compromiso con el feminismo no pasa por la necesidad de encontrar referentes literarios que representen al sujeto femenino desde una perspectiva liberadora, ¿desde qué experiencia biográfica te viene ese compromiso?

MG: Mira, mi compromiso con el feminismo, viene muy inconscientemente desde los quince años. En la preparatoria tomé un curso con un profesor de geografía muy inteligente y muy reaccionario. En su clase, empezamos a interesarnos en la tragedia griega, justamente en Esquilo, en Las coéforas, la primera parte de su trilogía La Orestíada, donde aparece una pitonisa, Casandra, hija de Hécuba y Príamo, y quien, al desairar a Apolo que se enamoró de ella, fue castigada por el Dios a profetizar a pesar suyo y a convertirse en la concubina de Agamennón, y por tanto a ser sacrificada junto con él por Clitemnestra y su amante Egisto. Ese destino violento e injusto que le esperaba, y esa terrible capacidad, la del furor mántico que la obligaba a profetizar a pesar suyo y, lo más terrible, a no ser creída por los suyos a quienes les vaticinaba la esclavitud y la muerte, me parecía como muy injusto; y el hecho de que el Dios la castigase así porque había rehusado ser su amante y la obligase a serlo de Agamennón y que muriera junto a él por el hacha asesina de Clitemnestra. Quizá de allí venga mi preocupación por la condición femenina, por el sentido de lo femenino en la historia, pero no lo entendía yo así, es una racionalización a posteriori. Entonces, ¿por dónde va mi feminismo? Pues desde muy, muy al principio, mi feminismo también quizá venga de un extrañamiento con mi propio cuerpo. Yo iba mucho al cine y era el cine de Greta Garbo, Jean Harlow, de esas mujeres maravillosas, Katharine Hepburn, de esos personajes muy bien vestidos, exclama con la misma admiración que le debieron producir aquellas vivencias que vuelven a surgir en esta pesquisa de palabras justas. Pero mi madre también era maravillosa, clamorea, se vestía increíblemente bien y usaba esos zorros que se usaban en la época, esos zorros que se describen en el tango y que cantaba Gardel cuando de repente se reencuentra con una antigua novia ya envejecida que lleva "unos zorros envejecidos”, y con la cual cantaba en otro tiempo “los versos de Rubén”. Yo nací en el treinta. Era una época en que las mujeres se pintaban, susurra para enfatizar cierta delicadeza femenina, se vestían mucho, usaban rosas artificiales en el vestido, se ponían sombrero. No salían sin sombrero a la calle. Y yo iba al cine y yo veía a esas mujeres y yo me veía y decía: “¡No! ¡Pero tengo la nariz muy larga, tengo la nariz del emperador romano, mi cuerpo no es mi cuerpo que yo quisiera tener;”. Entonces empecé a reconstruir los cuerpos y mi propio cuerpo. Mis lecturas críticas ya adultas trabajan la mirada del otro sobre el cuerpo femenino y la constitución de un estereotipo femenino construido de manera arbitraria por la mirada masculina.

IV: A raíz de este homenaje que le acabamos de dar a Jean Franco en las V Jornadas Metropolitanas auspiciadas en la Casa Lamm, ¿podrías decirnos cómo ves tú el status quo de la producción feminista aquí en México?

MG: Hay una producción teórica muy vinculada a la producción teórica canónica, que es la que se produce en los Estados unidos y en Francia. Estamos muy vinculados con la producción canónica de los Estados Unidos, porque nuestro sistema académico está cada vez más mimetizado con el sistema académico norteamericano. Se quiere que lleguemos a tener el mismo sistema.

IV: ¿Según tú, se daría más el mimetismo que el diálogo entre las producciones teórico-críticas de ambos lado del Río Grande? 
MG: Sí, hay mucho más mimetismo que diálogo. Encuentro que hay muy poco diálogo entre los textos. Hay imitación de fórmulas teóricas pero no creo que haya diálogo entre los textos. En los textos que escribí ayer, pensaba establecer un diálogo con Jean. Yo he aprendido mucho de Jean Franco y espero que ella de mí, como debe de ser en un verdadero diálogo intelectual. No sé si necesariamente en la conversación, aunque hemos tenido diálogos intelectuales importantes, sino en la lectura en los textos de ambas. Entonces, yo quería ayer, hacer homenaje a ese diálogo. Y hay cosas de las que discrepo de Jean Franco y hay cosas en las que me nutro de Jean Franco, ¿entiendes? Me gustaría que los textos engendraran otros textos. Hay una forma de crítica que es muy creativa y casi colinda con la creación y que es la de Carmen Boullosa. Me interesa por ejemplo lo que hacen las francesas. Me gustan mucho Nicole Loraux y Sissa, porque me da una cantidad posible de entradas a los mitos fundacionales y que para mí son siempre muy ricos porque te producen mucha posibilidad de lectura tanto crítica como creativa. Encuentro que el tipo de crítica que se hace en Chile, es fascinante porque es muy intelectualizada y muy rigurosa, pero puede ser en cierta medida esterilizante por excesiva.

IV: ¿Estás pensando en Nelly Richard?

MG: No estoy haciendo ningún retrato hablado. Admiro mucho la maravillosa capacidad teórica y de síntesis de Nelly Richard en relación con los estudios culturales, así como también la de Eugenia Britto y, de otra manera, a Diamela Eltit, quien además de ser fundamentalmente novelista es una crítica brillante. Las tres no sólo tienen una base teórica muy sólida sino que además innovan y por eso son creativas.

IV: Y sin embargo existe también un discurso crítico que ha denunciado la crítica creativa y poética propia de algunos ensayistas hispanohablantes, a ambos lados del Atlántico, y que se consideró poco rigurosa, en los casos particulares de Ortega y Gasset y de Octavio Paz.

MG: Yo trabajo con teoría. He leído mucho. Pero mi crítica es más bien creativa aunque sea una crítica bastante rigurosa. Yo me dejo llevar mucho por el lenguaje y por las asociaciones poéticas y es la teoría que a mí me interesa. Y creo que también interesa porque cuando doy una ponencia a la gente le gusta lo que estoy haciendo. Y siempre hay como una cosita que le da una vuelta de tuerca. Encuentro que Nelly es brillantísima, extraordinaria, a veces hasta me da pavor, porque es una gente muy racional, por lo menos intenta ser muy racional. Yo creo que la crítica que se está produciendo en Estados Unidos es una crítica que está programada por el estado, de una manera indirecta, pero que está programada para hacer de las universidades núcleos vacíos de saber que no tiene ninguna relación con el mundo real. En un texto que yo iba a leer ayer decía yo que el mundo de la crítica latinoamericana de Estados Unidos cabe o en un pañuelo o en un congreso. Porque uno se encuentra a toda la gente. Uno se interrelaciona por los congresos donde uno va esforzando el mismo tipo de crítica mimetizando lo que en ese momento se determina como teoría fundamental y que encorseta brutalmente al texto literario porque no le permite ser texto literario sino ser texto trabajado por el marco teórico. Y a mí, me parece horrendo. Pienso que es una cosa política muy violenta en contra de lo intelectual porque el intelectual tiene un papel muy importante en la vida pública y política en América Latina y en Francia. En Estados Unidos, hasta los '50 fue muy importante. Pero en Estados Unidos, han esterilizado totalmente la vida intelectual. Se repite eternamente el mismo tipo de discurso, con la excepción del que 
produce la gente más profunda y original, como las que ya he mencionado o como Sylvia Molloy o Josefina Ludmer, para sólo mencionar unas cuantas, entre las más destacadas. Podemos decir que está un Bloom, que está un Steiner, que aunque vive en Suiza, se lee mucho en Estados Unidos, que está un Said o una Gayatri Spivak, etc. Que de alguna manera, son muy originales, pero también constriñen a la crítica un vocabulario totalmente preestablecido en lo que tú metes todo, todo es subalterno. Oyes un discurso en Michigan, y lo oyes en Chile, y son los mismos discursos. No me interesan. Creo que los intelectuales, los críticos y los escritores tienen que dar cosas nuevas, ver la realidad desde aspectos completamente diferentes, inusitados, prohibidos. Transgredir. Y es lo que está pasando con la literatura que la están programando a cierto tipo de esquemas absolutamente específicos que van a tener un mercado. Se interrumpe y diluye lo dicho con solemnidad volviendo a evocar París. Pero al mercado me gustaría entrar, te digo, para ganarme un departamento en París. Risas. Me encantaría tener un departamento allí porque tengo muchos amigos, lo adoro. Viví allí cinco años.

IV: Volvamos ahora a tu participación en Chile, en el XXXII Congreso Internacional de Literatura Iberoamericana, que tuvo lugar en Santiago del 29 al 3 de julio de 1998. Has hablado del papel del subcomandante Marcos y has manifestado ciertas diferencias con el discurso de Octavio Paz, a quien mencionaste como "cacique intelectual”. Quisiera saber si su fallecimiento te ha facilitado la crítica pública de su discurso porque supongo que al Paz vivo no se le criticaba con demasiada facilidad.

MG: Es quizá como tú dices, la figura de Paz era muy poderosa y respetada y la gente no se atrevía a hacer críticas directas, aunque hubo sin embargo varias, por ejemplo la de Jorge Aguilar Mora con La divina pareja, un texto complicado, a veces confuso, quizá indigesto, pero interesante. Hace algunos años, un poeta mexicano joven, Pedro Serrano, empezó a trabajar una tesis doctoral sobre Elliot y Paz, de la que ha publicado varios fragmentos, algunos en vida de Paz, y su síntesis analiza con más profundidad muchos aspectos de la obra del poeta, tanto desde el punto de vista estético como político. Han aparecido varios fragmentos en revistas diversas y espero que pronto se publique en forma de libro. Desde 1989 yo he trabajado sobre Sor Juana Inés de la Cruz y he publicado varios textos que en muchos casos discrepan de lo que Paz escribió en Las trampas de la fe, y esos libros aparecieron en 1995 y en 1996, además de varios ensayos en publicaciones diversas desde 1989 y un ensayo en inglés que leí en una universidad de los Estados Unidos, donde ya hablaba como en mi ensayo sobre Marcos y Paz que leí en el Congreso de Chile; de Paz, como un antropófago, un enorme Huitzilopochtli, pero no de todo el país sino de un dios que devoraba a Sor Juana y la integraba a su propio cuerpo.

IV: En tu intervención en Chile también hablaste del subcomandante Marcos pero no explicaste tal vez cómo Marcos, no siendo indígena y con las dificultades de diálogo que tiene con el gobierno, podría llegar a darles voz a los chiapanecos.

MG: Decir eso es ya tan paternalista. Apenas estoy empezando a trabajar en lo de Marcos. El texto que escribí es un work in progress y lo tengo que trabajar mucho por eso. Una de las cosas que, a mí, me impresiona más de Marcos es que Marcos se dejó trabajar por lo indígena.

IV: Sí, Yvon Lebot menciona ese proceso de aculturación del subcomandante antes de la lucha. 
MG: Claro y estaba diez años trabajando con los indígenas y él tiene esas historias de Antonio - se acaba de publicar un texto de él en una revista nueva, un texto creativo en donde todo se lo dicta el indio Antonio. Es un personaje que ya murió y que no se sabe si es un personaje creado por Marcos pero que le trasmitió junto con otros indígenas al mundo indígena. Marcos empezó como un revolucionario clásico, dentro de la tradicional izquierda marxista-leninista y el camino trazado por el Che Guevara, y algunos de los terrorismos latinoamericanos. Se metió a Chiapas para tratar de cambiar las cosas de Chiapas. Pero Chiapas lo cambió a él. Y el discurso de Marcos es un discurso totalmente híbrido. Es un discurso totalmente definido por sistemas teóricos europeos que conoce bien — porque ha leído mucho—, por mucha literatura —-porque él tiene mucho tiempo para leer-, y al mismo tiempo toda una relación con el mundo indígena que a veces hace desconcertante su escritura, que en ocasiones puede ser hasta cursi, y en otras es de una fuerza enorme.

IV: No obstante su estilo ha llamado mucho la atención, e incluso ha hecho que llamara la atención fuera de México, en Francia sobre todo.

MG: Sí, a veces es extraordinario Marcos. Yo creo que tiene un sentido del humor también extraordinario.

IV: En El arte de la fuga, Sergio Pitol señala esa característica del discurso de Marcos.

MG: Sí. Y ese es otro ingrediente que me parece una maravilla. A mí, me choca mucho eso que "le da voz a otro" porque es una noción totalmente colonial. Quizá este tema de la voz que alguien le da a los otros podría documentarse de nuevo con el ejemplo de la pitonisa apolínea, la de un ser humano que es penetrado para dar a luz una palabra que no es la suya sino la del Dios, una mujer cuya corporeidad es casi insoportable y sin embargo funciona sólo como receptáculo de la voz divina, a la manera de un instrumento que otros hacen sonar. Entonces parecería que darle la voz a otros es una forma de ningunear o rebajar esos otros. "Marcos le da voz a ..." Odio eso. Creo que Marcos tiene su propia voz pero una voz que se ha modulado con las voces múltiples de las lecturas europeas, de las lecturas del Distrito Federal, de las lecturas místicas y proféticas que lee y de un mundo indígena que él ha asimilado profundamente en diez años de trabajo con ellos. Pero no es indígena tampoco. Me parece fundamental replantear toda la cuestión. Un buen acercamiento a Marcos es el texto mencionado de Yvon Le Bot, quien ha trabajado varias de las guerrillas sudamericanas. Le Bot analiza cómo el zapatismo, no sólo por Marcos, sino por el movimiento mismo, tal y como se ha conformado con la participación indígena, ha resemantizado el idioma de la guerrilla. La figura de Marcos que a veces parece asimilarse con la de esa Pitia, tantas veces aquí mencionada, es decir cuando traduce la voz indígena que él vincula sobre todo con el llamado “viejo Antonio", receptor de una vieja tradición oral, ha ido modelando también su propia voz, la que ha sido trasmitida por los medios modernos, el Internet, la prensa, la televisión...

IV: ¿Se te ha pasado por la mente alguna vez ir a la selva de Chiapas?

MG: Sí, me interesa mucho.

IV: ¿Qué opinaste del largo silencio de Marcos?

MG: Creo que Marcos calló porque no había ninguna razón para hablar en cuanto el diálogo entablado con el gobierno no tenía ninguna salida, y decidió callar como antes de que se produjese la insurrección. Se hicieron muchos chistes, que Marcos no hablaba porque quería ir al fútbol y que a lo mejor estaba de incógnito en alguno de los grandes estadios 
europeos, otros, más trágicos, pensaban que lo habían asesinado, otros decían que estaba vivo y que lo habían visto. ... interrumpe la oración la estrepitosa sirena de una ambulancia que pasa por una calle cercana y se aplaza la conversación en el ir y venir cada vez más familiar de la mano de Margo a su taza y de su taza al plato ... una figura muy importante porque es una figura de intermediación, pero no de intermediación pura por la que pasen las cosas sino que también él hace pasar cosas personales. Pero también está ese mundo prehispánico, indígena con toda una mentalidad muy particular.

IV: Solamente en los países subdesarrollados o en vía de desarrollo, las mujeres alcanzan puestos de poder muy importantes. Ni Madame Mitterand ni Hillary Clinton logran lo que Benazir Bhutto o Violeta Chamorro. ¿Qué posibilidades tenemos de ver a una mujer a la cabeza de México?

MG: Creo que tienes razón, pero aunque es importante que las mujeres alcancen puestos políticos y administrativos muy altos, como por ejemplo la Thatcher que fue siniestra, es fundamental que las mujeres participen de manera más activa en las cosas más cotidianas, más definitivas y que transforman la sociedad y sobre las que antes no tenían influjo de la manera en que pueden tenerlo hoy. En México, las mujeres han jugado un papel muy importante dentro de lo que hoy se conoce como la sociedad civil, por ejemplo durante el terremoto de 1985 o en la lucha por el aborto o la diferencia sexual, en las universidades, en puestos administrativos y políticos, en cuadros medios, en la educación más directa de sus hijos, en su actitud frente al machismo, etc.

IV: ¿En México, cómo ha transformado el zapatismo la percepción de la mujer?

MG: Marcos cuenta cómo al hablar con la gente y escuchar los consejos personales de las tribus, decían: “¡No, no!, porque la mujer en cuanto empieza a movilizarse se prostituye, y esa labor de la familia... que la mujer no se desplace, que la mujer se quede en casa. Que sea el hombre quien se desplace, quien hable, quien ocupe puestos importantes”. La fuerza y la participación de las mujeres zapatistas ha aumentado mucho en estos últimos años. Se logró cambiar en parte la concepción que tenían los indígenas de las mujeres y en los últimos enfrentamientos que ha habido las mujeres han resistido de manera ejemplar. Es significativo cómo en la matanza de Acteal, acaecida en diciembre de 1997, los asesinos se ensañaron con las mujeres y qué ejemplo de resistencia cívica dieron luego ellas. Hay una fotografía impresionante que muestra a una mujer que rechaza a un soldado mucho más alto que ella y que con aire feroz empuña un fusil, y ella con una mano lo detiene y en la otra lleva una gallina. Es el símbolo de la más perfecta domesticidad y el heroísmo.

Estuve en París, hace como un mes y medio y vi mucho cine. Me llamó mucho la atención el cine del tercer mundo. Es el país donde más se puede ver cine del tercer mundo. Y vi unas películas maravillosas. Y la película que más me impresionó, de las películas que vi, es una película iraní de una niña de dieciocho años que filma la historia de dos niñitas, que sus padres las mantenían encerradas en la casa porque la madre es ciega, y un padre que tiene terror a que las hijas estén expuestas al mundo porque son mujeres. Es una película maravillosa con una perfección formal y una sobriedad de una belleza escueta extraordinaria. Desgarrador sin ser cursi. De una justeza, de una perfección... me pareció maravillosa. Se llama La pomme. Y es una niña de dieciocho años. Entonces, una mujer en un mundo tan terriblemente cerrado como el iraní donde las mujeres son lo peor de lo peor, porque están veladas, porque están encerradas. Si fueran hombres no las hubieran encerrado. Es la 
condición femenina en su más precaria desnudez exhibida por una chica de dieciocho años. En los países del Tercer Mundo tenemos más canales de vida afectiva y a la vez social. En Estados Unidos, la corrección política (political correctness) y la liberación femenina conducen a caminos muy peligrosos, veamos nada menos que el caso Clinton-Mónica Lewinsky. Todavía tenemos formas de vida que son afectivas y que son sociales. En Estados Unidos, la liberación de la mujer está negando cosas muy importantes.

IV: ¿Crees que está deserotizando toda la sociedad?

MG: Me parece, creo que no debe desterrarse de una sociedad el erotismo, la seducción, el flirteo, la palabra espontánea. Creo que en Estados Unidos se ha llegado a extremos muy grotescos, aunque creo fundamental que se regulen las relaciones entre los sexos y que no se permitan los distintos tipos de violaciones a que siempre ha estado sujeta la mujer, me parece que se ha llegado en ese país a algo funesto, a algo que favorece una estratificación y una rigidez muy peligrosas y nocivas, justamente por la fluidez enorme de las comunicaciones y el uso que se le da al erotismo, a la pornografía, al sexual harassment en la televisión, el cine, las revistas y hasta en el Internet.

IV: A modo de conclusión, ¿tienes algún proyecto que quisieras compartir?

MG: Estoy escribiendo una novela pero es un proyecto muy íntimo, muy en brouillon, entonces no me atrevo a plantearlo mucho. Es una novela que tiene que ver con el cuerpo también, la relación con el cuerpo biológico. Después del trabajo que hice sobre Marcos para el congreso de Chile, quisiera trabajar más lo de Marcos. Y ya tenía un libro sobre la novela folletín que estoy escribiendo. Esos son mis proyectos.

IV: Tras unos comentarios sobre los inauditos injertos de Orlan, una artista francesa que exhibe protuberancias en los temples en busca de un nuevo perfil maya por las calles de México, y con el recuerdo fugaz de Cindy Sherman y de Bataille, Margo regresa a uno de sus temas favoritos.

MG: Es delirante porque por más épater le bourgeois que quiera Orlán, es su cuerpo. Es un poco lo que hacían las monjas en el convento. No es tan obsoleto como parece. Porque las monjas utilizaban el propio cuerpo para operaciones de ascetismo para producir un estado anímico, que era como un delirio, la relación con Dios. Es el cuerpo como materia prima para producir algo.

IV: Nuestros cuerpos se alejaron entonces de la grabadora para descubrir juntos, $y$ motivados por la cafeína, el enjambre de artesanía colorida que ofrecía la plaza de Coyoacán, esa tarde de verano. Margo había dejado de sugerir imágenes y sensaciones para convertirse ahora en una guía entre los puestos de la plaza atiborrados de vestigios de un presente incierto. Desde uno de ellos, nos llegó el saludo exaltado de un hombre joven, de pelo largo, que le arregla a Margo sus joyas de plata. Nos despedimos frente a la librería del Parnaso y en la muchedumbre perdí de vista los rizos negros de Margo llevándose con ellos el enigmático secreto de mi regreso a la estación de metro. Cerezas y hadas malas, toman pocas y llevan hartas. 